\title{
Factors Inhibiting the Use of Bamboo in Building Construction in Ghana: Perceptions of Construction Professionals
}

\author{
Desmond Opoku1, Joshua Ayarkwa², Kofi Agyekum²* \\ ${ }^{1}$ Department of Architecture, Kwame Nkrumah University of Science and Technology, Kumasi, Ghana \\ ${ }^{2}$ Department of Building Technology, Kwame Nkrumah University of Science and Technology, Kumasi, Ghana \\ Email: "agyekum.kofi1@gmail.com
}

Received 1 November 2015; accepted 1 February 2016; published 5 February 2016

Copyright (C) 2016 by authors and Scientific Research Publishing Inc.

This work is licensed under the Creative Commons Attribution International License (CC BY).

http://creativecommons.org/licenses/by/4.0/

(c) () Open Access

\begin{abstract}
There is a growing concern of the integration of bamboo as a material into the building construction industry even though its potential is underscored. Certain factors serve as barriers to the use of bamboo in building construction. This study employed a questionnaire survey which sought to investigate the perceptions of 84 Architects and 100 Senior Managers of small and medium scale Building construction firms on the factors that influence the use of bamboo in building construction. Relative Importance Index and Chi-squared tests were performed to identify the significant factors that influence the use of bamboo in building construction. The results showed that the building contractors considered nonspecification of bamboo for building projects by Architects, inadequate bamboo processing companies in Ghana and insufficient cooperation from government to be the key factors which influence the use of bamboo for building construction. The results further showed that the Architects considered lack of knowledge in bamboo detailing, limited knowledge of bamboo and lack of expertise to use it, and inadequate bamboo processing companies to be the key influential factors inhibiting the use of bamboo in building construction. The results are of value to the construction industry as it identifies significant factors which influence the usage of bamboo in building construction. Promotion of bamboo usage in building construction should be given the needed publicity to create the awareness of its potential as a building material.
\end{abstract}

\section{Keywords}

Architects, Building Contractors, Bamboo, Barriers, Ghana

\footnotetext{
${ }^{*}$ Corresponding author.
}

How to cite this paper: Opoku, D., Ayarkwa, J. and Agyekum, K. (2016) Factors Inhibiting the Use of Bamboo in Building Construction in Ghana: Perceptions of Construction Professionals. Materials Sciences and Applications, 7, 83-88. 


\section{Introduction}

The building construction industry contributes immensely to the economy of every nation, especially developing countries where there are increasing demands for buildings to supply homes for dwellers and other activities [1]. According to Anand [2], inadequate building construction capacity could act as a constraint on economic capital investment programmes. Building construction in Ghana in recent times is faced with high costs of building materials due to high percentages of imported materials. This has resulted in high deficiencies in housing supply. Cardoso [3] reiterated that to alleviate this problem of deficiency in housing supply there is the need to embrace the use of local materials like timber and bamboo which are paramount in the Ghanaian building construction industry.

Ghana's forest timber production area is declining in an increasing manner in both size and productivity due to unecological logging practices and over utilization of traditional timber species. The extreme exploitation of the forest has beckoned on authorities to put in place strict regulations which have eventually reduced the quantity of timber supplied to the furniture and construction industries [4]. According to Paudel and Solomon-Ayeh [5], bamboo which is characteristically synonymous to timber should be exploited as an alternative material to alleviate the problem of insufficient timber species used in building construction in Ghana.

The use of bamboo in building construction worldwide has evolved from simple pole construction to more sophisticated construction. Bamboo can serve as a material for the whole or part of the construction of a building [6]. According to Gutiérrez [7], there has been an ancient exploration of bamboo for construction, and this is due to the fact that it appears to be a tailor made material for use as a building component. In contrast to other materials, bamboo appears round, straight, smooth, strong and beautiful. It possesses constructional properties like high tensile strength, high strength to weight ratio and high specific load bearing capacity, hence confirming its potential as a material for building construction [5] [8]-[11]. Comparatively, bamboo possesses high residual strength to absorb shocks and impacts like timber, and this makes it a highly suitable material for construction of houses to resist seismic and high wind forces [12].

Bamboo has seen extreme exploitation as a building construction material in the construction industry in China, India, Latin America, amongst others. It is used extensively as scaffolding, props, ladder, partition walls, reinforcement, landscape, windows, doors, roofing, trusses, ceiling and flooring. Even though bamboo is propagated in Ghana, its exploitation is yet to be desired. This study sought to assess the perceptions of construction professionals on factors that inhibit the use of bamboo for construction in Ghana.

\section{Materials and Methods}

This study sought to assess the views of Architects and Building Construction professionals on factors that inhibit the use of bamboo for building construction in Ghana. The study employed a structured questionnaire survey consisting of eighty four Principal Architects of registered architectural firms in good standing, and one hundred Senior Managers of small scale building construction firms in Kumasi and Accra. These professionals were purposively selected based on their level of experience in the use of bamboo for building construction. Thirteen factors which inhibit the use of bamboo for building construction which have been extensively studied were extracted from literature [6] [13]-[16]. These barriers were pre-tested in a multiple pilot study using questionnaires involving some selected experienced construction practitioners to evaluate their applicability to the current study. They agreed to its applicability to the current study and suggested modification and rewording of some few factors.

The administered questionnaire was structured to include both open and closed ended questions. The questionnaire was divided into two sections. The first section sought information about the respondents' profile, whilst the second section assessed the perceptions of the professionals on the factors that inhibit the use of bamboo in the Ghanaian building industry.

The various factors identified were analyzed using relative importance index. That is the various responses on each factor were weighted and their values were ranked in an order of importance to outline the level of significance of each factor. Chi Squared test was further used to establish the level of agreement or differences in the views of the Architects and Building contractors on the factors. The hypotheses stated are as follows:

$\mathrm{H}_{0}$ : there is no difference between the responses of the professionals on the factors that inhibit the use of bamboo.

$\mathrm{H}_{1}$ : there is a difference between the responses of the professionals on the factors that inhibit the use of bam- 
boo for building construction. $\mathrm{H}_{0}$ denotes the null hypothesis and $\mathrm{H}_{1}$ denotes the alternative hypothesis. Significant level $(\alpha)=0.05$, and the null hypothesis $\left(\mathrm{H}_{0}\right)$ is rejected if $X_{\text {cal }}^{2}>X_{0.05}^{2}$.

\section{Results and Discussion}

\subsection{Respondents' Profile}

The average years of experience of the firms surveyed in the construction market were between 15 and 25 years, implying that all the firms have significant experiences in the building industry. Fifty percent (50\%) of the Senior Managers interviewed had Bachelor of Science Degrees, $40 \%$ had Master of Science Degrees and 10\% had Doctorate Degrees. For the Architects, almost all of them were holders of Master of Architecture (MArch) Degrees. These notwithstanding, all the respondents from the Architectural and Building Construction firms provided services to both the public and private sectors.

\subsection{Perceptions of Respondents on Factors That Inhibit the Use of Bamboo in Building Construction}

Table 1 shows a summary of the perceptions of the respondents on the factors that inhibit the use of bamboo for building construction. The results show that in the views of the building contractors, nonspecification of bamboo for building projects by Architects, inadequate bamboo processing companies in Ghana, insufficient cooperation from government, problems of social acceptability and limited knowledge of bamboo, and lack of expertise to use it are the five key factors which inhibit the use of bamboo for building construction in Ghana. The Architects on the other hand considered lack of knowledge in bamboo detailing, limited knowledge of bamboo and lack of expertise to use it, inadequate bamboo processing companies in Ghana, lack of durability when untreated and competition from other building materials to be the key factors inhibiting the use of bamboo for building construction in Ghana.

These results affirm the fact that, limitations in the extensive use of bamboo in building construction in Ghana is because of the barriers to its usage [13] [14]. Generally, from the views of the respondents, the limited use of bamboo as a material in building construction in Ghana is as a result of the impact of the various factors serving as barriers to its usage.

Table 1. Barriers to the use of bamboo in Ghana.

\begin{tabular}{|c|c|c|c|c|c|}
\hline \multirow[t]{2}{*}{ No. } & \multirow[t]{2}{*}{ Factors } & \multicolumn{2}{|c|}{ Building Contractors } & \multicolumn{2}{|c|}{ Architects } \\
\hline & & RII & Rank & RII & Rank \\
\hline 1 & Architects (consultants) do not specify them for building projects & 0.8906 & $1^{\mathrm{st}}$ & 0.514 & $13^{\text {th }}$ \\
\hline 2 & Inadequate bamboo processing companies in Ghana & 0.8264 & $2^{\text {nd }}$ & 0.8000 & $3^{\text {rd }}$ \\
\hline 3 & Insufficient cooperation from government & 0.8264 & $2^{\text {nd }}$ & 0.6914 & $10^{\text {th }}$ \\
\hline 4 & Problem of social acceptability (bamboo is considered for the poor) & 0.8226 & $4^{\text {th }}$ & 0.7486 & $6^{\text {th }}$ \\
\hline 5 & Limited knowledge of bamboo and lack of expertise to use it & 0.8222 & $5^{\text {th }}$ & 0.8343 & $2^{\text {nd }}$ \\
\hline 6 & Lack of knowledge in bamboo detailing & 0.8000 & $6^{\text {th }}$ & 0.8800 & $1^{\text {st }}$ \\
\hline 7 & Lack of management skill in the use of bamboo & 0.7925 & $7^{\text {th }}$ & 0.7371 & $7^{\text {th }}$ \\
\hline 8 & Poor processing techniques in Ghana & 0.7925 & $7^{\text {th }}$ & 0.7371 & $7^{\text {th }}$ \\
\hline 9 & Highly susceptible to fire & 0.7623 & $9^{\text {th }}$ & 0.7143 & $9^{\text {th }}$ \\
\hline 10 & Less durable if not treated for permanent use & 0.7585 & $10^{\text {th }}$ & 0.7829 & $4^{\text {th }}$ \\
\hline 11 & Treated bamboo is expensive & 0.6717 & $11^{\text {th }}$ & 0.6057 & $12^{\text {th }}$ \\
\hline 12 & Not readily available & 0.6113 & $12^{\text {th }}$ & 0.6057 & $12^{\text {th }}$ \\
\hline 13 & Competition from other building materials & 0.5585 & $13^{\text {th }}$ & 0.7543 & $5^{\text {th }}$ \\
\hline
\end{tabular}




\subsection{Level of Agreement between the Perceptions of Respondents on Factors Inhibiting the Use of Bamboo for Building Construction}

The Chi-Squared test of the contingency table (Table 2) was used to determine whether there existed any differences in the perceptions of the respondents on the factors that inhibit the use of bamboo for building construction [17].

Results from the Chi-Squared test showed that there are no significant differences in the perceptions of the two respondents on the factors that inhibit the use of bamboo in building construction. All the factors but "nonspecification of bamboo for building projects by Architects" showed no significant differences. From this result it can be said that there exist a level of agreement between the two groups of respondents on the factors inhibiting the use of bamboo in building construction in Ghana.

The identified factors were further analyzed based on their strengths (S), weaknesses (W), opportunities (O) and threats (T) (SWOT Analysis) associated with their usage. These strengths, weaknesses, opportunities and threats are presented in Table 3.

\section{Conclusions}

The study sought to assess the perceptions of Architects and Building Construction Professionals on factors that inhibit the use of bamboo in building construction in Ghana. From the perceptions of the respondents, all the identified factors inhibited the use of bamboo in building construction. That is, in the views of the Architects, lack of knowledge in bamboo detailing, limited knowledge of bamboo and lack of expertise to use it, inadequate bamboo processing companies in Ghana, lack of durability when untreated, and competition from other building materials were considered as factors which inhibit the use of bamboo for building construction in Ghana. Also, according to the building construction professionals, nonspecification of bamboo for building projects by Architects, inadequate bamboo processing companies in Ghana, insufficient cooperation from government, problems of social acceptability and limited knowledge of bamboo, and lack of expertise to use it were the five key factors which were considered to inhibit the use of bamboo for building construction in Ghana. The chi-squared test performed on the factors revealed no significant differences between the views of the Architects and the Building Construction professionals on the factors inhibiting the use of bamboo for building construction. From the SWOT analysis, it could be observed that though bamboo has its own strengths and opportunities, there are also threats and weakness which need to be considered in specifying its usage. To assist in popularizing the use of bamboo for building construction in Ghana, the following are recommended:

Table 2. Chi-squared values between respondents on barriers to the use of bamboo.

\begin{tabular}{ccc}
\hline No. & FACTORS & Chi-Squared Value \\
\hline 1 & $X_{\text {cal }}^{2}$ \\
2 & Architects (consultants) do not specify them for building projects & 0.287 \\
3 & Lack of bamboo processing companies in Ghana & 0.023 \\
4 & Insufficient cooperation from government & 0.028 \\
5 & Problem of social acceptability (bamboo is considered for the poor) & 0.032 \\
6 & Limited knowledge of bamboo and lack of expertise to use it & 0.049 \\
7 & Lack of knowledge in bamboo detailing & 0.047 \\
8 & Lack of management skill in the use of bamboo & 0.041 \\
9 & Poor processing techniques in Ghana & 0.041 \\
10 & Highly susceptible to fire & 0.043 \\
11 & Less durable if not treated for permanent use & 0.005 \\
12 & Treated bamboo is expensive & 0.012 \\
13 & Not readily available & 0.001 \\
\hline
\end{tabular}


Table 3. SWOT analysis of bamboo in building construction in Ghana.

\begin{tabular}{|c|c|}
\hline STRENGTHS & WEAKNESSES \\
\hline - $\quad$ Bamboo is readily available in Ghana & - $\quad$ Lack of knowledge in bamboo detailing \\
\hline $\begin{array}{l}\text { - Bamboo is durable and easy to use in its natural state with } \\
\text { less processes to go through }\end{array}$ & $\begin{array}{l}\text { - It is difficult to control the quality of bamboo because of its } \\
\text { different species }\end{array}$ \\
\hline $\begin{array}{l}\text { - It is Easy to obtain bamboo in any quantity for temporary } \\
\text { uses }\end{array}$ & - $\quad$ Highly susceptible to fire if not treated to be fire proof \\
\hline $\begin{array}{l}\text { - Using bamboo for temporary areas in building construction } \\
\text { requires low technical know how }\end{array}$ & - $\quad$ Untreated bamboo is prone to fungi and insect attacks \\
\hline - Bamboo does not break easily & $\begin{array}{l}\text { - Irregular shape of bamboo culms makes it difficult to work with } \\
\text { as compared to timber }\end{array}$ \\
\hline
\end{tabular}

- Bamboo is very beautiful in its appearance

OPPORTUNITIES THREATS

- Bamboo has multiple uses in building construction

- Bamboo faces competition from other building materials

- $\quad$ Shortage and high cost of timber makes bamboo a promising material to be considered in building construction

- Contractors and architects are ready to embrace bamboo as a popular building material in building construction

- Bamboo is considered as a material for the poor

- There is insufficient cooperation from government to support bamboo in building construction

- $\quad$ There are inadequate bamboo processing techniques

- There is limited knowledge of bamboo and lack of expertise in building construction

- $\quad$ There is lack of knowledge in bamboo detailing in Ghana

- Architects should consider bamboo as a primary material in their specification for building designs and Construction;

- The use of bamboo in less used areas in building construction should be promoted to create the awareness of its potential as a building material;

- Research into bamboo as an alternative to timber should be encouraged in building construction institutions to enhance basic promotion of the potential of bamboo;

- Measures should be put in place to eliminate the factors which inhibit the use of bamboo in building construction.

\section{References}

[1] Anaman, K.A. and Osei-Amponsah, C. (2007) Analysis of Causality Links between the Growth of the Construction Industry and Growth of the Macro-Economy in Ghana. Construction Management and Economics, 25, 951-961. http://dx.doi.org/10.1080/01446190701411208

[2] Anand, H.S. (2000) Criteria HRD Issues Pertaining to Construction and Other Workers in the Informal Sector. Draft Report Prepared for IFP/SEED under a Project Entitled Urban Informal Sector Support Programme in India Funded by the ILO and UNDP.

[3] Cardoso, R.D., Okai, E.N.A., Eshun, A.A. and Haizel, K.E. (2007) Review of the Domestic Timber Market with an Emphasis on Off-Forest Reserve Timber Production and Management in Ghana. Timber Industry Development Division, SGS Ghana Ltd, Tema, 1-3.

[4] Ayarkwa, J. (1998) New Marketable Ghanaian Timber Species for Furniture and Construction. Wood News, Forestry Research Institute of Ghana (FORIG), Kumasi, 13-18.

[5] Paudel, S. and Solomon-Ayeh, K.A. (2004) Bamboo School Building. International Network for Bamboo and Rattan (INBAR) Publication, Kumasi.

[6] Tekpetey, S.L (2006) Adding the Utilization of Bamboo Resources in Ghana through Property Search and Enhanced Processing. ICBR, Beijing.

[7] Gutiérrez, J.A. (2000) Structural Adequacy of Traditional Bamboo Housing in Latin America. International Network for Bamboo and Rattan 2000, Technical Report, 19, 10-15 
[8] Tada, T., Hashimoto, K. and Shimabukuro, A. (2010) Challenges, Opportunities and Solutions in Structural Engineering and Construction: On characteristics of Bamboo as Structural Materials. Taylor \& Francis Group, London, 527532.

[9] Ghavami, K. (2005) Bamboo: Functionally Graded Composite Material. Asian Journal of Civil Engineering (Building and Housing), 4, 1-10.

[10] Van der Lugt, P., van der Dobbelsteen, A.A.J.F. and Janssen, J.J.A. (2005) An Environmental, Economic and Practical Assessment of Bamboo as a Building Material for Supporting Structures. Construction and Building Materials, 20, 648-656. http://dx.doi.org/10.1016/j.conbuildmat.2005.02.023

[11] Yao, W. and Li, Z. (2003) Flexural Behavior of Bamboo-Fiber Reinforced Mortar Laminates. Cement and Concrete Research, 33, 15-19. http://dx.doi.org/10.1016/S0008-8846(02)00909-2

[12] Shyamasundar, S.K. and Vengala, J. (2008) Promotion of Bamboo Housing System and Recent Development. IPIRTI, India.

[13] Obiri, B.D. and Oteng-Amoako, A.A. (2007) Sustainable Development of the Bamboo Industry in Ghana. Ghana Journal of Forestry, 21-22, 14-27.

[14] Mankin, E. (2007) Truck-Safe Bamboo Bridge Opens in China. http://www.eurekalert.org/pub_releases/2007-12/uosc-tbb121107.php

[15] Gangopadhyay, P.B. (2003) Bamboo Resources as a Rural Livelihood Option in Madhya Pradesh, India. Paper submitted to XII World Forestry Congress, Quebec City, March 2003.

[16] Madhab, J. (2003) The Green Gold: Under Exploited Wealth of the North East India. Dialogue, 5, 45-52.

[17] Keller, G. and Warrack, B. (2004) Statistics for Management \& Economics. 6th Edition. www.pbs.org/newshour/updates 